\title{
Zadania pielęgniarki w opiece nad seniorem w terminalnej fazie raka gruczołowego płuc
}

\author{
Nurse's tasks in the care of a senior in the terminal stage of lung \\ adenocarcinoma
}

MONIKA SANDER-GRABOWSKA ${ }^{1}$

1 Studenckie Koło Naukowe Nauk o Zdrowiu, Instytut Nauk o Zdrowiu PUZ we Włocławku. Opiekun Koła: dr Beata Haor

http://dx.doi.org/10.21784/IwP.2021.005

\section{Streszczenie}

Wstęp. Rak płuca stanowi w Polsce pierwszą przyczynę zgonów z powodu nowotworów. Najistotniejszymi czynnikami wpływającymi na ryzyko wystąpienia raka płuca są: palenie tytoniu (czynne i bierne), ekspozycja na pierwiastki rakotwórcze, czynniki genetyczne, choroby płuc (zwłóknienie płuc, przewlekła obturacyjna choroba płuc, krzemica) oraz nieodpowiednia dieta (mała ilość spożywanych warzyw i owoców).

Cel. Celem niniejszej pracy jest przedstawienie zadań pielęgniarki w opiece nad seniorem w terminalnej fazie raka gruczołowego płuc

Prezentacja przypadku. Pacjentka lat 74 w 5. dobie hospitalizacji przyjęta w oddział z rozpoznaniem raka gruczołowego płuc, powodu znacznych dolegliwości bólowych, postępującej kacheksji, zaparć oraz problemów z oddychaniem.

Wnioski. W terminalnej fazie raka gruczołowego płuc dominującymi problemami pielęgnacyjnymi seniora są: ból, duszność, zaparcia spowodowane leczeniem opioidami, niedożywienie wynikające z postępu choroby nowotworowej, zmiany w obrębie jamy ustnej. Rolą pielęgniarki w opiece nad seniorem w terminalnej fazie raka gruczołowego płuc jest przede wszystkim udział w łagodzeniu wszystkich dolegliwości wynikających z postępu choroby.

Słowa kluczowe: rak płuc, opieka paliatywna, proces pielęgnowania, ICNP ${ }^{\circledR}$ 


\begin{abstract}
Introduction. Lung cancer is the main cause of death due to cancer in Poland. The most important factors that influence the risk of developing lung cancer are: smoking (active or passive), exposure to carcinogens, genetic factors, lung dieseses and bad diet (eating not enough vegetables).

The aim. The aim of this study is to present the tasks of a nurse in the care of a senior in the terminal stage of lung adenocarcinoma.

Case presentation. A 74-year-old patient on the $5^{\text {th }}$ day of hospitalization was admitted to the ward diagnosed with lungs adenocarcinoma, which was the cause of significant pain, progressive cachexia, constipation and respiratory problems.

Conclusion. In the terminal stage of lung adenocarcinoma, the dominant care problems for seniors are: pain, dyspnea, constipation caused by opioid treatment, malnutrition resulting from the progression of cancer, oral lesions. Main goal of a nurse in the care of a senior in the terminal stage of lung adenocarcinoma is mainly participation in alleviating ailments resulting from disease progression.
\end{abstract}

Keywords: lung cancer, palliative care, $\mathrm{ICNP}^{\circledR}$, nursing process

\title{
Wstęp
}

Rak płuca stanowi w Polsce pierwszą przyczynę zgonów z powodu nowotworów [1]. Zgodnie z klasyfikacją Światowej Organizacji Zdrowia (WHO - World Health Organization), nowotwory płuca możemy podzielić na drobnokomórkowe i niedrobnokomórkowe. Gruczolakorak należy do raków niedrobnokomórkowych i stanowi 35\% wszystkich nowotworów płuca. Jest on zazwyczaj małą zmianą w obwodowych częściach płuca. Posiada skłonność do tworzenia przerzutów w okolicznych węzłach chłonnych oraz odległych narządach. Już we wczesnych etapach choroby dochodzi do rozsiewu krwiopochodnego. Ten typ nowotworu jest zazwyczaj naciekiem płucnym, czasem guzem pojedynczym lub licznymi rozproszonymi po płucach guzkami [2]. Występuje najczęściej u kobiet i u osób niepalących [3, 4]. 
Najistotniejszymi czynnikami wpływającymi na ryzyko wystąpienia raka płuca są: palenie tytoniu (czynne i bierne), ekspozycja na pierwiastki rakotwórcze, czynniki genetyczne, choroby płuc (zwłóknienie płuc, przewlekła obturacyjna choroba płuc, krzemica) oraz nieodpowiednia dieta (mała ilość spożywanych warzyw i owoców) [3].

\section{Cel}

Celem niniejszej pracy jest przedstawienie zadań pielęgniarki $\mathrm{w}$ opiece nad seniorem $\mathrm{w}$ terminalnej fazie raka gruczołowego płuc.

\section{Prezentacja przypadku}

Pacjentka lat 74, przyjęta do oddziału opieki hospicyjnej z powodu narastających dolegliwości bólowych, postępującej kacheksji, problemów z oddychaniem oraz zaparć. W rozpoznaniu lekarskim rak gruczołowy płuc - proces rozsiany. Kobieta w 5 . dobie hospitalizacji. W dniu przyjęcia: waga $46 \mathrm{~kg}$, wzrost $168 \mathrm{~cm}, \mathrm{RR} 110 / 60 \mathrm{mmHg}$, tętno $60 \mathrm{ud} /$ min, temp. $37,3^{\circ} \mathrm{C}$. U chorej stwierdzono zmiany w obrębie jamy ustnej pod postacią pleśniawek. Pacjentka jest niedożywiona.

Z wywiadu wynika, że w grudniu 2019 r. lekarz onkolog podjął decyzję o przerwaniu leczenia pacjentki cytostatykami i rozpoczęciu leczenia paliatywnego, ponieważ w trakcie przyjmowania trzeciej serii chemioterapii niespodziewani u pacjentki wystąpiła encefalopatia wielozawałowa oraz nasilenie zaburzeń krążenia mózgowego pod postacią ustępującego niedowładu połowiczego prawostronnego. Z tego powodu w listopadzie 2019 r. była hospitalizowana w oddziale neurologii. Kobietę poddano rehabilitacji i farmakoterapii. Objawy niedowładu ustąpiły. Kobieta została objęta domową opieką hospicyjną. Chora z powodu swojego stanu zdrowia wykazywała objawy depresji. Niechętnie współpracowała z rehabilitantem przychodzącym raz w tygodniu w celu wykonywania ćwiczeń oddechowych i fizycznych dostosowanych do aktualnych możliwości. Nie chciała także stosować się do zaleceń lekarza hospicjum - umiarkowana aktywność ruchowa, przyjmowanie 1,5-2,0 l płynów dziennie, spożywanie warzyw i owoców, spacery z asekuracją. 
Większość czasu spędzała w łóżku. Stan psychiczny pacjentki ulegał dalszemu pogarszaniu. Postępująca choroba nowotworowa spowodowała wystąpienie u pacjentki kacheksji oraz silnych dolegliwości bólowych. Z powodu bólu lekarz podjął decyzję o zmianie leków przeciwbólowych z tramadolu 300 mg 1-0-1 na plastry Fentanyl $50 \mu \mathrm{g} / \mathrm{h}$ zmieniane co $72 \mathrm{~h}$, uzupełniane o dawki ratujące w postaci morfiny o natychmiastowym uwalnianiu. U pacjentki wystąpiły zaparcia spowodowane leczeniem opioidami. Skarży się na duszność.

Kobieta mieszka z synem, synową i wnukiem w mieszkaniu trzypokojowym w bloku. Warunki mieszkaniowe i sanitarne dobre. Pacjentka utrzymuje się z emerytury. Rodzina bardzo zaniepokojona stanem pacjentki.

Poniżej zaprezentowano propozycję planu opieki pielęgniarskiej w odniesieniu do wybranych problemów pacjentki w terminalnej fazie raka gruczołowego płuc. Wykorzystane zostały terminy z ICNP ${ }^{\circledR}$ - wersja z 2019 r. [6, 7, 8, 9, 10, 11, 12, 13].

Diagnoza 1: Ból wynikający z postępu choroby nowotworowej ICNP ${ }^{\circledR}$ : Ból [10023130]

Interwencje:

- Ocenianie bólu [10026119]

- Identyfikowanie postawy wobec bólu [10009654]

- Administrowanie lekiem przeciwbólowym [10023084]

- Monitorowanie odpowiedzi na leczenie [10032109]

- Nauczanie radzenia sobie z bólem [10019489]

- Zarządzanie bólem [10011660]

- Ewaluacja odpowiedzi na zarządzanie bólem [10034053]

- Zachęcanie do odpoczynku [10041415]

- Współdziałanie z pacjentem [10035915]

Wynik ICNP ${ }^{\circledR}$ : Zredukowany ból [10027917] 
Diagnoza 2: Duszność spoczynkowa spowodowana postepujacym procesem nowotworowym

ICNP ${ }^{\circledR}$ : Duszność spoczynkowa [10029422]

Interwencje:

- Zmierzenie oddechów [10046338]

- Ocenianie statusu oddechowego [10036786],

- Ocenianie perfuzji tkanek [10030775],

- Monitorowanie statusu (wydolności) oddychania [10012196]

- Pozycjonowanie pacjenta [10014761]

- Zarządzanie bezpieczeństwem środowiska [10042507]

- Terapia tlenem [10039369]

- Nauczanie o ćwiczeniach [10040125]

- Zachęcanie do stosowania techniki oddychania lub odkasływania [10006834]

Wynik ICNP ${ }^{\circledR}$ : Duszność spoczynkowa [10029422]

Diagnoza 3: Zaparcia spowodowane leczeniem opioidami ICNP ${ }^{\circledR}:$ Zaparcie [10000567]

Interwencje:

- Nauczenie o reżimie diety [10026525],

- Współdziałanie przy reżimie diety [10026190]

- Podawanie płynów [10039330]

- Zarządzanie reżimem ćwiczeń [10023890]

- Administrowanie lekiem [10025444]

- Leczenie zaparcia [10044729]

- Wykonywanie lewatywy [10043618]

Wynik ICNP ${ }^{\circledR}$ : Efektywna defekacja [10028403]

Diagnoza 4: Niedożywienie spowodowane postepujacym procesem nowotworowym

ICNP $^{\circledR}$ : Zaburzony status odżywienia [10025746]

Interwencje:

- Ocenianie statusu odżywienia [10030660] 
- Ważenie pacjenta [10033323]

- Monitorowanie spożycia pokarmów [10036614]

- Nauczenie o reżimie diety [10026525],

- Współdziałanie przy reżimie diety [10026190]

- Monitorowanie odżywiania [10036032]

- Zarządzanie statusem odżywienia [10036013]

Wynik ICNP ${ }^{\circledR}$ : Zaburzony status odżywienia [10025746]

Diagnoza 5: Zmiany na śluzówkach jamy ustnej (afty) wynikające z procesu nowotworowego i terapii

ICNP $^{\circledR}$ : Zaburzona błona śluzowa jamy ustnej [10026967]

Interwencje:

- Ocenianie wzorca higieny jamy ustnej [10037913],

- Asystowanie w higienie [10030821]

- Administrowanie lekiem i roztworem [10001804]

- Pielęgnacja jamy ustnej [10032184]

Wynik ICNP ${ }^{\circledR}$ : Zaburzona błona śluzowa jamy ustnej [10026967]

\section{Dyskusja}

$\mathrm{W}$ opiece nad pacjentką $\mathrm{w}$ terminalnej fazie raka gruczołowego płuc zastosowano model pielęgnowania wg Virginii Henderson, który polega na zdefiniowaniu deficytów, określeniu, w jakim zakresie pacjent wymaga pomocy w zakresie jego potrzeb. Wg autorki modelu funkcją pielęgniarki jest asystowanie choremu człowiekowi w procesie powrotu do zdrowia, bądź też towarzyszenie w ostatnich chwilach życia i zapewnienie mu godnych warunków umierania. W przypadku opisywanej pacjentki asystowanie polega na towarzyszeniu jej w ostatnich chwilach życia oraz zapewnienie jej godnej śmierci. Zadaniem pielęgniarki jest więc utrzymanie ciała pacjentki w czystości, pomoc w spożywaniu posiłków, dążenie do łagodzenia dolegliwości bólowych, zapewnienie wsparcia psychicznego, a tym samym poprawa jakości życia [5]. Drugim modelem opieki zastosowanym $\mathrm{w}$ tym przypadku jest model adaptacyjny wg Calisty Roy. Zgodnie z jego założeniami pielęgniarka poprzez 
udzielanie wsparcia dąży do adaptacji pacjenta i jego rodziny do zmian, które są spowodowane chorobą. W przypadku opisywanej pacjentki oznacza to pomoc w akceptacji sytuacji, w jakiej znalazła się chora oraz jej rodzina oraz zrozumienie, że śmierć jest naturalnym procesem [5].

\section{Wnioski}

Zadaniem pielęgniarki $\mathrm{w}$ opiece nad seniorem $\mathrm{w}$ terminalnej fazie raka gruczołowego płuc jest przede wszystkim udział w łagodzeniu wszystkich dolegliwości wynikających z postępu choroby, a także zapewnienie optymalnych warunków do zaspokojenia potrzeb takich, jak odżywianie, utrzymanie higieny, wypoczynek. Zadaniem pielęgniarki jest również udzielenie wsparcia psychicznego zarówno pacjentowi, jak i jego rodzinie.

\section{Bibliografia/Bibliography:}

1. Wojciechowska U., Czaderny K., Ciuba A. i wsp. Nowotwory złośliwe w Polsce w 2016 roku. Krajowy Rejestr Nowotworów. Ministerstwo Zdrowia, Warszawa 2018;9,26:44-75.

2. Krzakowski M., Kawecki A. Nowotwory złośliwe. Postępowanie wielodyscyplinarne. Leczenie systemowe, chirurgia, radioterapia. Wydawnictwo Czelej, Lublin 2012:62.

3. Batura-Gabryel H. Kompendium pulmonologiczne. Uniwersytet Medyczny im Karola Marcinkowskiego w Poznaniu, Poznań 2013;288-289,291, 294-300.

4. Kułakowski A., Skowrońska-Gardas A. Onkologia podręcznik dla studentów medycyny. Wydawnictwo Lekarskie PZWL, Warszawa 2014;119-121, 123-125.

5. Zarzycka D. Wybrane teorie pielęgniarstwa. [w:] Ślusarska B., Zarzycka D., Zahradniczek K. (red.): Podstawy pielęgniarstwa. Podręcznik dla studentów i absolwentów kierunku pielęgniarstwo i położnictwo. Tom I. Założenia teoretyczne. Wydawnictwo Lekarskie PZWL, Warszawa 2011; 183-187,207. 
6. de Walden-Gałuszko K., Kaptacz A. Pielęgniarstwo opieki paliatywnej. Wydawnictwo Lekarskie PZWL, Warszawa 2017;7-13,33-43,50-51,5961, 101-103,175,178-179,341-342.

7. Krajnik M., Malec-Milewska M., Wordliczek J. Chory na nowotwór. Kompendium leczenia somatycznych objawów towarzyszących. Oficyna Wydawnicza Medicaleducation, Warszawa 2015;72-73,171-172,176-179, 385.

8. Jeziorski A. Onkologia. Wydawnictwo Lekarskie PZWL, Warszawa 2015; 76,206-216.

9. Koper A. Pielęgniarstwo onkologiczne, Wydawnictwo Lekarskie PZWL, Warszawa 2011;397-398,401-403, 405,07,409,410-412.

10. Ciałkowska-Rysz., Dzierżanowski T. Medycyna paliatywna. Wydawnictwo Termedia, Poznań 2019;486.

11. Krajnik M., Malec-Milewska M., Wordliczek J. Chory na nowotwór. Kompendium leczenia somatycznych objawów towarzyszących. Oficyna Wydawnicza Medicaleducation, Warszawa 2015;72-73,171-172,176-179, 385.

12. https://www.icn.ch/what-we-do/projects/ehealth/icnp-browser

13. Kilańska D. Międzynarodowa klasyfikacja praktyki pielęgniarskiej - ICNP ${ }^{\circledR}$ w praktyce pielęgniarskiej. Wydawnictwo Lekarskie PZWL, Warszawa 2014. 